\title{
Great Battles Require Strategic Discipline-And Washington Needs It in This Crisis
}

\begin{abstract}
The US must learn tact and discipline in the style of Churchill and Kissinger to weather the Covid-19 storm and come out of this crisis on the right side of history.
\end{abstract}

At a dark moment of World War II, in August 1942, British Prime Minister Winston Churchill flew to Moscow to have dinner with Soviet Premier Joseph Stalin. The ideological gap between them was far greater than the gap between the US and China today. Yet Churchill didn't hesitate to cooperate with Stalin. Why not?

An old strategic adage holds that in any great war, one should focus on the main battlefield and not get distracted by secondary issues. The great Prussian military theorist Carl von Clausewitz wrote, "The talent of the strategist is to identify the decisive point and to concentrate everything on it, removing forces from secondary fronts and ignoring lesser objectives." US Secretary of State Mike Pompeo, who graduated first in his class from West Point, should know this strategic adage well.

Today, if Churchill were leading America's war against a pandemic, he would advise focusing on the main battlefront, Covid-19, rather than getting distracted by the ongoing geopolitical contest with China. Indeed, just as he dined with Stalin, Churchill would advise America to cooperate with China. Sadly, few voices in America are recommending such Churchillian wisdom.

Only President Trump, with his usual flair for unusual moves, could put in a phone call to Chinese President Xi Jinping on March 27, 2020. Yet, at the same time, the Trump administration has been sending contradictory signals. Its campaign against Huawei has not abated; the Trump administration is considering additional measures to restrict the supply of chips to the Chinese technology giant. On March 27, President Trump also signed a law obliging Washington to raise global support for Taiwan, a direct slap in the face for Beijing. Churchill, if he were alive today, would disapprove of these contradictory approaches. He would have said, "Focus on the main battlefront."

America has seen huge spikes in Covid-19 cases. Indeed, America now has more cases than any other country in the world. More dangerously, the number

Originally published in The Hill, Apr 10, 2020 
of fatalities could run from as high as 200,000 to 1.7 million, as per projections based on the Centers for Disease Control and Prevention (CDC) scenarios. Off and on, America has desperately needed masks, ventilators, gowns, gloves, and other personal protective equipment (PPE) for health care personnel and other workers.

On March 29, 2020, a plane from Shanghai landed at JFK Airport in New York, carrying 12 million gloves, 130,000 N95 masks, 1.7 million surgical masks, 50,000 gowns, 130,000 hand-sanitizer units, and 36,000 thermometers. Yet, these amounts were a drop in the ocean. Even France ordered a billion masks, a vast majority of them from China.

Instead of relying on domestic commercial channels, the US government should work with the Chinese government. To foster such effective governmentto-government cooperation, a few simple steps should have been taken. The first would have been to stop insulting China; it was unwise, for example, for the Trump administration to try to persuade the G-7 countries to call Covid-19 the "Wuhan virus." The main lesson we should take away from this massive global outbreak is that all 7.5 billion inhabitants of Planet Earth have become like the passengers on the ill-fated cruise ship off Japan, the Diamond Princess: Our destinies, especially our health destinies, are intertwined. We have to work together to solve this crisis. It's not smart to argue about who sprung the leak when a boat is sinking; what matters is how we respond to it. A clear signal from the Trump administration should have been to stop scapegoating China, which would calm countries and markets all around the world, including the US.

There's one other simple step that Churchill would advise the US to take: President Trump should announce that he will immediately rescind all the tariff and non-tariff measures he imposed on China, with the understanding that China will do the same. This may not lead to a major boost in trade or economic growth immediately. It will, however, send a powerful signal to the markets that when Covid-19 begins to retreat, both the economic growth and the international trade will bounce back faster.

President Trump will lose nothing from making such an announcement. And he could extend it further by withdrawing all threats to raise tariffs on allies such as the European Union, Japan, Canada, and Mexico. The markets will take note of these soothing measures. We all feel nostalgic for the world before the pandemic. By sending signals that the world will eventually return to the status quo ante, we will build up confidence in the future that will come when Covid-19 recedes, as it surely will.

When we return to the status quo ante, we may well return once again to a resumption of the US-China geopolitical contest. Before America do so again, however, it may wish to heed the advice of its own strategic thinkers, like Henry Kissinger and George Kennan. It was unwise of America to plunge headlong into a geopolitical contest against China without first working out a comprehensive long-term strategy, as I argue in the book, Has China Won?

If America presses the "pause" button on the US-China geopolitical contest now, as Churchill would advise it to do, this pause should provide American strategic thinkers the time to ponder all the dimensions of this contest before plunging in again. It also would provide Americans an opportunity to discover where the rest of 
the world stands on this issue. During the Cold War, all of Europe enthusiastically supported America. Today, it is unclear that Europe would do so: Some Italians in Rome played the Chinese National Anthem on public loudspeakers, and Serbia's president cried and kissed the Chinese flag, after urgently needed medical supplies arrived in both countries from China; in Spain, citizens trended "Gracias China" on Twitter to thank China for sending medical supplies and personnel; the French foreign minister expressed his gratitude to China for providing much-needed medical supplies, including surgical masks, protective suits, and gloves.

This doesn't mean that all will be lost for America in this geopolitical contest. It only means that America will have to emulate the wisdom of great strategic thinkers, like Churchill, Kissinger, and Kennan — and think hard before making its next, critical moves.

Open Access This chapter is licensed under the terms of the Creative Commons AttributionNonCommercial-NoDerivatives 4.0 International License (http://creativecommons.org/licenses/bync-nd/4.0/), which permits any noncommercial use, sharing, distribution and reproduction in any medium or format, as long as you give appropriate credit to the original author(s) and the source, provide a link to the Creative Commons license and indicate if you modified the licensed material. You do not have permission under this license to share adapted material derived from this chapter or parts of it.

The images or other third party material in this chapter are included in the chapter's Creative Commons license, unless indicated otherwise in a credit line to the material. If material is not included in the chapter's Creative Commons license and your intended use is not permitted by statutory regulation or exceeds the permitted use, you will need to obtain permission directly from the copyright holder.

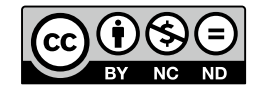

